\title{
CAPACITY BUILDING PROGRAM FOR URBAN REGENERATION: THEORY INTO PRACTICE
}

\author{
O. OZCEVIK \& I. AKCAKAYA \\ Department of Urban and Regional Planning, Istanbul Technical University, Turkey.
}

\begin{abstract}
This paper examines the progress of urban regeneration policies with reference to the Turkish context and a capacity building project experienced in the city of Istanbul. Following the 1999 Marmara earthquake, the Zeytinburnu District in Istanbul was assigned as the 'pilot area for urban regeneration' according to the disaster preparedness policies of the Istanbul Earthquake Master Plan. Following this, the local municipality of Zeytinburnu was determined to demand knowledge and skills for urban regeneration practices. This paper focuses on local practices in comparison with some general trends: changes in local governance and urban regeneration, and the tendency to share out responsibilities through stakeholders via capacity building and physical, economic and legal arrangements, strategies developed with multi-stakeholders through sustainable urban regeneration, strategies for putting theory into practice for the implementation of built local knowledge. The aim of this paper is to reveal the outcomes on 'institutional and community capacity building' in Zeytinburnu as a prior municipality of Istanbul in the means of urban regeneration, and to open a discussion on these outcomes. The paper highlights the importance of capacity building in the disaster preparedness process through outcomes of the Matra REGIMA Project that is in progress in Zeytinburnu Municipality.

Keywords: capacity building, participatory event, urban governance, urban regeneration.
\end{abstract}

\section{INTRODUCTION}

Zeytinburnu is an advantageous settlement due to its location and closeness to central districts. However, being a first focus of illegal settlements in Turkey and sheltering a major portion of the migration to Istanbul, it has lacked a proper urbanization process and therefore today suffers from a dense and unqualified development. Such negative development presents a threat in terms of providing quality of urban life and the future of the settlement in the face of natural disasters. In fact, following the 1999 Marmara earthquake, it is obvious that this type of urban development is clearly a threat for any region in Istanbul.

Zeytinburnu District has been charged with an important mission after the 1999 Marmara earthquake, being selected as a case area for disaster mitigation among similar problematic districts of Istanbul. Zeytinburnu has been chosen as the 'pilot area' by the Istanbul Metropolitan Municipality (IMM) within the Istanbul Earthquake Master Plan (IEMP) following this disaster. To date, urban regeneration projects have accelerated in Zeytinburnu District, while lack of knowledge and skills for urban regeneration are investigated by either municipal staff or local communities. These capacity areas are project management, decision-making process, and public participation. Studies to fill these gaps have been carried out and important steps have been taken so far. The most important steps are the establishment of the Zeytinburnu Urban Planning Atelier (ZESAT), preparation of the 2006-2009 corporate strategic plan, and selection of flagship projects that play a pioneering role in urban regeneration and institutional capacity building.

The concepts of 'governance' and 'participation' are being recently assimilated by Turkey. Within this period, Zeytinburnu Municipality has added an international dimension to its regeneration projects in collaboration with the Dutch Government and the Dutch PRC Bouwcentrum Company as well as an academic dimension with the support of a consultant group from Istanbul Technical University (ITU), Department of Urban and Regional Planning. Within this cooperation in order to 
achieve a practical regeneration project, local district organization, a training framework for capacity building and a particular participatory approach were aimed to be determined. Based on these achievements, the next step will be towards longer-term objectives and enabling more efficient public participation.

The aim of this paper is to reveal the outcomes on 'institutional capacity building' as a prior municipality of Istanbul in the means of urban regeneration, and to open a discussion on these first outcomes. In Section 2 the basic facts of Zeytinburnu District and Municipality in terms of natural, physical, and social structures are presented including the problems that Zeytinburnu suffered after the 1999 Marmara earthquake. Section 3 explains the efforts of Zeytinburnu Municipality to tackle those problems, particularly initiatives that were taken in the field of 'urban regeneration'. Section 4 focuses on implemental outcomes of the Dutch-Turkish project partnership, the Matra REGIMA Project, conducted in Zeytinburnu. Finally, Section 5 discusses the importance of capacity building for collaborative urban regeneration action and presents recommendations for future projects.

\subsection{Context: governance and capacity building in urban regeneration}

Urban regeneration offers integration of problem solving, potentials, strategies, and projects within the social, environmental, cultural, and economic dimensions [1]. Urban regeneration has been defined by Roberts [2] as 'a comprehensive and integrated vision and action which leads to resolution of urban problems and which seeks to bring about a lasting improvement in the economic, physical, social and environmental conditions of an area that has been subject to change.' According to Roberts [2], urban regeneration should be constructed with a long-term, more strategic purpose in mind. Thus, the main aspects of urban regeneration are the need for a general strategic agenda and crosssector integration. Based on this Roberts [2] identifies a number of principles as the hallmark of urban regeneration. Considering the scope of this study, the most important ones are that urban regeneration should:

- analyze the condition of an urban area in detail;

- develop strategy and resulting programs according to the terms of sustainable development;

- set clear objectives that are quantified wherever possible;

- provide consensus through participation and co-operation;

- measure and monitor strategy improvement towards the achievement of objectives and the changing nature and influence of internal and external forces that act upon urban areas.

According to Carter [3], a strategic approach provides potential benefits in relation to the external environment and therefore the partnership approach is a critical element in adopting a strategic approach to urban regeneration. Also, Roberts [2] states that urban regeneration theory is principally related to the institutional and organizational dynamics of the management of urban change.

In recent years, new elements have been introduced in urban management policies to provide success in urban regeneration management. It can be said that traditional forms of local government with hierarchical forms of decision making are replaced by less-hierarchical, multi-actor approaches within urban management [1]. In experiencing the new 'governance' label involving social welfare, environmental protection, education and physical planning practices through national, regional and local levels of partnerships, the role of the local government has become increasingly significant in terms of local democracy [4]. Thus, qualifications of partnerships gain importance to achieve local democracy. Particularly, the vitality of capacity building and institutional development at the national and subnational levels involved in partnership concept is emphasized in the Habitat II context [5]. 
Being one of the tools for realizing local governance, Local Agenda 21 addresses the role of local authorities who are closest to the people and can play a vital role in educating, mobilizing and responding to the public to promote sustainable urban and community development [6]. The aim of the context of Agenda 21 is to carry out a community-wide learning process about global and local dimensions of sustainable lifestyle and development. Such a learning process results in a set of concrete proposals for achieving substantive objectives as well as in the establishment of what is often referred to as 'institutional capital' [7]. Institutional capital, as 'institutional capacity', can be assumed to be embodied in social relations and interactions and is developing as a result of the social learning process [7].

Within the perspective of sustainable lifestyle and development, Khakee [7] considers the 'institutional capital' approach according to intellectual, social, and political components criteria of Healey [8] for constituting a new institutional source. He defines intellectual capital as 'various knowledge resources built on previous experiences, scientific investigations and understanding of people, places and issues'. It also includes shared and enriched knowledge and understanding in order to assist decisions that people support [7]. In Healey's [8] study, 'social capital' as social network resources refers to facilitating collaboration between a broad range of partners in order to achieve support and enhance the capacity to coordinate actions. Parallel to this statement, Khakee [7] defines the power relations, linkages between networks and range of social relations as criteria for evaluating the social capital. Thirdly, 'political capital' implies commitment among both politicians and government staff and citizens to shape agendas and take actions. Hence, it is necessary for building consensus, influencing policy-thinking and mobilizing resources to achieve this [7].

At this point, 'institutional capacity building' with its new learning network building, social network linking and collaborative approaches has become one of the major issues in Zeytinburnu Municipality's planning agenda following the 1999 Marmara earthquake. Accordingly, this paper focuses on Zeytinburnu Municipality's efforts of institutional capacity building [9]. In the following sections, the results of the REGIMA Project, which is operated by ITU-PRC and supported by the Dutch Ministry of Foreign Affairs, Matra Social Transformation Program, in order to answer such needs of Zeytinburnu Municipality are focused upon. The Matra REGIMA Project promotes the structure of 'institutional capacity building' for Zeytinburnu Municipality's regeneration actions simultaneously and functions as a strategy for transforming theory into practice.

\section{BASIC FACTS OF ZEYTINBURNU DISTRICT}

Zeytinburnu District is located on the south coast of the western side of the province of Istanbul, covering a total of 1,142 ha with an approximate population of 248,000 (Fig. 1). The district is directly connected to the E-5 highway and the Bosphorus Bridge. Due to its location it is possible to access the Trans European Motorway (TEM) and thus also connect to the Fatih Sultan Mehmet Bridge. Therefore, it is an important window of Istanbul opening to the outer world. The district was governed by the Fatih Municipality in the east and the Bakirkoy Municipality in the west until it became a municipality in 1953; in 1957 it became the 14th district of Istanbul. Considering the population density in the districts of Istanbul in the year 2000, in Zeytinburnu the density is 20,639 persons per square kilometer. This makes Zeytinburnu the eighth most densely populated district in Istanbul.

Even though Zeytinburnu has been a part of the urban life and area of Istanbul since the Roman ages, and there are various historical buildings and remnants of this period, it did not have a vivid history of its own; and as it has been continuously settled in the later periods, it is accepted as one of the newest settlements of Istanbul. During the Byzantine period, as areas outside the city walls were unsafe due to sieges that the city often faced, they were not settled continuously. Together with the 


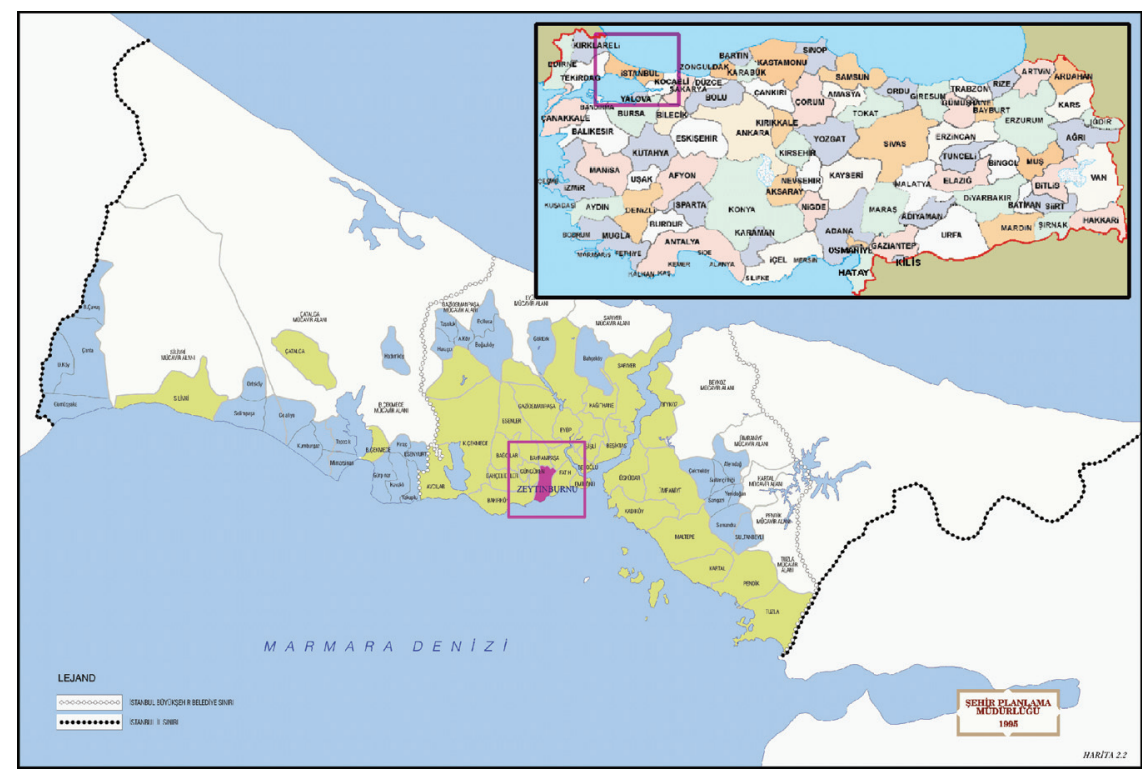

Figure 1: Location of Zeytinburnu District at the national and provincial scale.

foundation of , tanneries in the Ottoman times at today's Kazlicesme, settlements around these areas started to take shape slowly. By the year 1946 'illegal housing' started towards the north of Kazlicesme, shaping the identity of today's Zeytinburnu settlement.

Zeytinburnu District's population was 89,297 in the 1960 census. An increase due to the influence of development of squatters was observed though the rate of population increase in Istanbul was lower than the average until 1990. Thus, the district's population reached 247,669 in the 2000 census. The realized population growth rate for 10 years between 1990 and 2000 is $49.5 \%$, whereas the increase in the total population of Istanbul is far behind the increase in Zeytinburnu. The population increase after 1990 is related to the solution of the problems on deeds of a large part of the existing real estate and the opening of new settlements due to the construction of permitted buildings. Besides commercial activities and textile and leather industries, there are tombs, monasteries and churches of historical value as well as the historical Istanbul city walls in Zeytinburnu District.

\subsection{Identifying Zeytinburnu's problems after the 1999 Marmara earthquake}

When compared in terms of building intensity, it is seen that the building density of Zeytinburnu District is twice the building density of overall Istanbul. This constitutes a serious intensity and risk in terms of earthquake management. In particular, it must be considered that the transportation infrastructure will gain importance in such densities. The rate of buildings being reliable and strong in terms of structure within such intensity must be high within the total number of buildings.

As the rate of reinforced concrete skeleton structure in the district is $74.4 \%$ and the rate of briquette/brick structure is $21.7 \%$, about $96.1 \%$ of the buildings have this type of skeleton carrier system and back-filled wall. In the last 30 years, the recently developed areas consist of reinforced concrete structures since the rapid construction increase after 1970. Rapid construction resulted in a drop in the quality of buildings especially in structures used for housing purposes. On the other hand, 
more than $67 \%$ of the structures in Zeytinburnu District range between four and seven floors. In addition to building density, the fact that a considerable number of the buildings have a number of storeys that can be deemed as middle high or high is considered to increase the regional risk.

In a research carried out by ITU's Urban and Environmental Planning and Research Center, some assumptions have been made with regard to the inventory of a temporary settlement area in the Zeytinburnu District pilot region. It can be said that the demand expected to arise in this context will also shed light on the necessary potential and loss of temporary housings. The capacity that is revealed in this context is 4,000 housings. This fact requires that earthquake preparation studies are to be carried out urgently in Zeytinburnu District [10].

\section{LOCAL GOVERNMENT ACTIONS FOR DEALING WITH POST-DISASTER PROBLEMS}

Zeytinburnu Municipality has worked on several strategic actions in order to tackle the "urban regeneration' problems that occurred after the earthquake and came up on the agenda and to integrate those actions within the planning framework. The first action is the establishment of ZESAT, the second action is the preparation of the 2006-2009 corporate strategic plan, the third action is the flagship project that has a pioneering role in urban regeneration, and the fourth action is the institutional and community capacity building program.

\subsection{Action 1: Establishment of ZESAT}

Establishment of ZESAT is based on IEMP policies. The master plan, projected for 2010, has revised and captured some arrangements to let the City of Istanbul become a 'Global City' again, because of the pioneer role of the city within the membership process of Turkey into the EU, and integration obligation of the 2025 European year concept. The main objectives of urban planning ateliers in provincial and district scales are set as

- adaptation to the EU;

- acceleration of fine-tuning at the metropolitan scale;

- managing urban regeneration projects;

- supplying the expertise needs by organizing events, service provision, consultancy, and competition activities;

- developing close relations with civil society achieving result-oriented projects, monitoring and assessing regeneration activities.

In order to realize these objectives, an institution named Istanbul Urban Planning Atelier (ISAT) was built under the Department of Settlements and Urban Regeneration involved in IMM. In the light of these objectives, to achieve livable Zeytinburnu, ZESAT was established in 2003 to work in coordination with ISAT and to prepare implementation plans in accordance with upper-scale plans, all of which will support successful urban regeneration practices.

\subsection{Action 2: Improving institutional identity using strategic planning}

The second action is the preparation of the 2006-2009 corporate strategic plan of Zeytinburnu Municipality. Solutions to the problems related to urban regeneration were represented in the mission, vision statement, principles and strategic goals sections, which are the basis for a strategic plan. The mission of Zeytinburnu Municipality under rule of law is to improve Zeytinburnu and its 
people in accordance with Istanbul's historical, geographical and social structure, while its vision is to achieve a settlement that has harmony among its historical and cultural pattern, and its economy, security, sense of belonging, awareness and shared values of urban citizenship and solidarity, brand municipal philosophy, high service provision and quality, and lifelong development. The principles of the strategic plan are:

- transparency in decision-making, implementations and actions;

- accountability based on decentralization of service provision and meeting real needs;

- participation in decision-making within municipal organizations and for districts;

- justice in implementations and equity in services;

- efficiency and productivity for use of municipal resources;

- actions with sustainability rather than temporary solutions and instant decisions.

Prior implementation of the urban regeneration project is going to be completed at the end of 2008 as envisioned in the strategic plan. Strategic goals, objectives and actions related to urban service delivery are: 'excavation, protection, marketing and management of historical, cultural and natural assets', 'completion and implementation of urban regeneration plans according to the vision statement of the district', and 'increase the safety of the district for natural disasters'. The detailed explanations are represented in the performance criteria section of the plan.

\subsection{Action 3: Flagship project - Zeytinburnu Culture Valley urban regeneration project}

The third action is determining the priority among projects. Two coordinated projects set as flagship projects in Zeytinburnu enlighten the historical and cultural focuses and proposed related facilities with an integrated approach. The 1/5,000 scaled master plan for conservation is ratified by IMM. The first is the 'Sumer Neighborhood', which is determined to be the highest risk neighborhood for earthquake according to IEMP's pilot study. Although a condense study has been carried out with IMM, further legislation changes are needed and are being awaited. The second project is the 'Cultural Valley Project', which covers an area of 240 ha within Zeytinburnu District (Fig. 2). The project area is proclaimed as a renewal area, issued in Official Newspaper, June 23, 2006, according to Code No. 5366, which includes studies capturing renewal of historical and cultural structure, taking earthquake risk into account, coordinating different actors with the support of NGOs, universities and international agencies.

\subsection{Action 4: Capacity building for practicing Zeytinburnu Culture Valley Project}

The fourth action is about capacity building. In order to manage the urban regeneration process, corporate and social capacities should be strengthened in any settlement as well as Zeytinburnu. The first project phase in the renewal area is chosen as Merkezefendi Mosque and its surrounding which is also focused within a Matra Project supported by the Dutch Government. This project has added a social dimension to the technical studies that ZESAT carried out in cooperation with the Dutch Government, PRC Company, a consultant group from ITU's Department of Urban and Regional Planning and Human Settlements Association as a local NGO. Activities of the project are based on training for preparation of a communication and participation plan, and more importantly, gaining trust from local people in order to let them involve in the project in a more efficient manner. The disadvantage of less-understanding of 'governance' and 'participation' concepts is aimed to turn out to be an advantage while conducting the project. The following section gives information on 


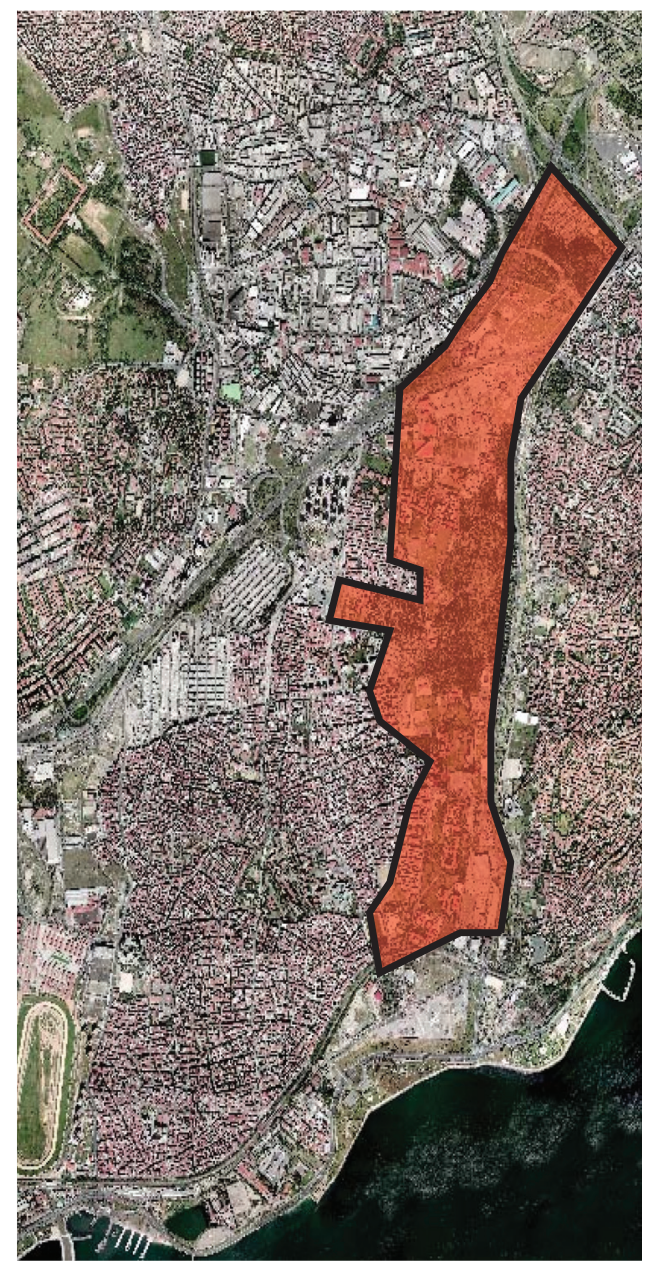

Figure 2: Zeytinburnu Culture Valley Project site within the district.

the Matra REGIMA Project, introducing its logical framework, pilot area, methodology and steps taken so far.

\section{THE MATRA PROGRAM FOR CAPACITY BUILDING}

Through the Matra Program, the Dutch Ministry of Foreign Affairs promotes the strengthening of the civil society in Central and Eastern Europe. Currently, Matra operates in 16 countries. Turkey was accepted in 2000 as a Matra beneficiary when it became a candidate for EU membership. Among the themes covered by the Matra Program are the development of housing policies and urban regeneration. These topics belong to the key expertise of PRC Bouwcentrum, which performed various Matra projects since the establishment of the Matra Program in 1993.

IMM in cooperation with ITU and NGOs has attempted to solve the urban problems in Zeytinburnu by initiating the Regeneration of Istanbul Metropolitan Area (REGIMA) Project. Knowing that the central government of Turkey is preparing a new Urban Regeneration Act to 
be passed at the national level, the initiators of REGIMA are determined to set a course for the project by using the new act as a solid basis for implementation and by seeking European collaboration in terms of professional project management, knowledge and experience in urban regeneration, and financial support. The existing relationship between the Turkish and the Dutch organizations has led to a mutual partnering to prepare the REGIMA Project within the Matra Program.

The REGIMA proposal has been submitted for a Matra subsidy program in 2004. Following an evaluation process, the REGIMA proposal has been selected as a candidate Matra project in 2005. Among the projects that Matra supports in capacity building is an ongoing project dated between June 2006 and November 2007, namely 'Urban Regeneration in Romania', to improve the capacity of homeowners' associations and local municipalities in sustainable housing management and integrated urban planning. The objective of the project is to contribute to the long-term improvement of the living conditions in the urban areas in Romania by initiating the process of urban regeneration and improving the housing conditions. The key target groups of this project are homeowners' associations of multi-apartment buildings, regional and national representatives, local municipalities, and the Association of Romanian Municipalities [11].

PRC was familiar with ITU through its European research networks. The existing collaboration was extended to involve Zeytinburnu Municipality and the Istanbul-based NGO, Human Settlements Association. Together with Dutch partners Vestia Interconsult and Urban Solutions, ITU jointly formulated the Matra proposal regarding a pilot project of REGIMA. In 2 years time, the project aims at providing training on citizen participation and project management to the local development actors, setting up a neighborhood communication center, and implementing a process model for an urban regeneration pilot project in Zeytinburnu. By doing this, the Matra REGIMA Project will act as a facilitator on the way from the 1999 Marmara earthquake to a disaster resistant livable future through disaster studies and reconstruction process (Fig. 3).

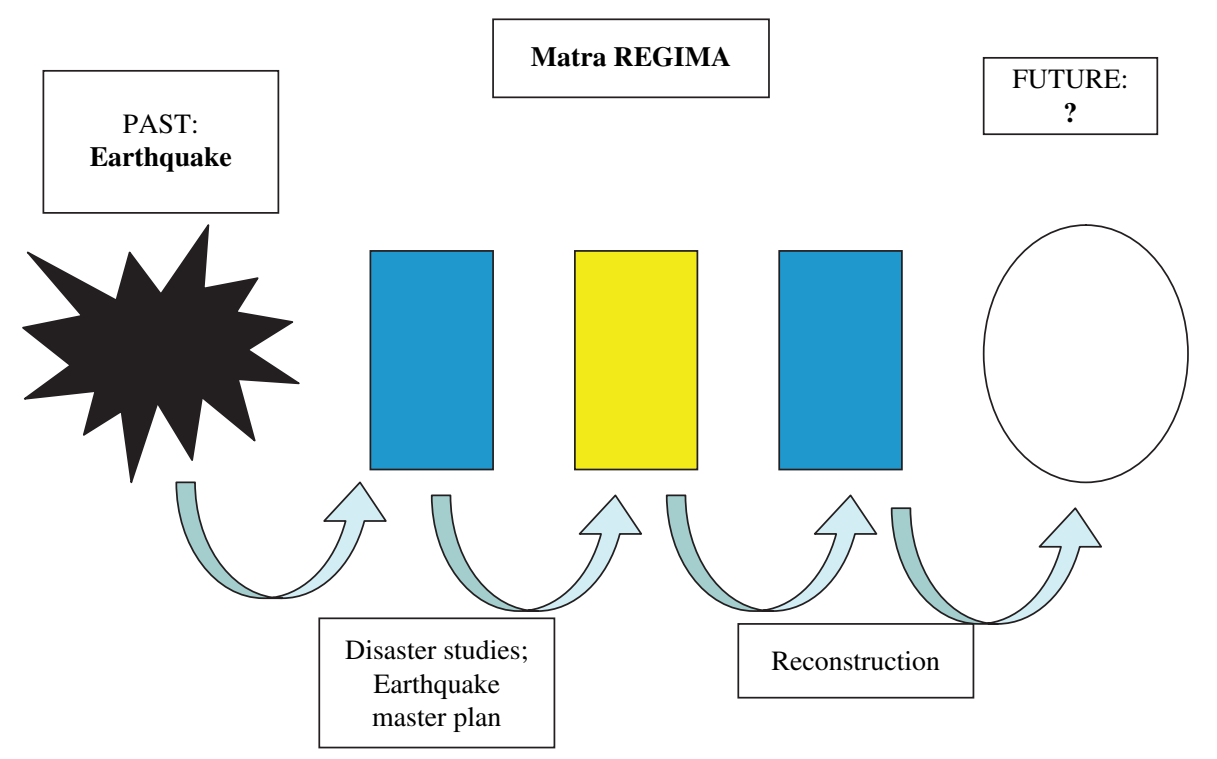

Figure 3: Logical framework of the Matra REGIMA Project. 


\subsection{Matra REGIMA Project methodology: the Dual Track Holistic Approach}

The Matra REGIMA Project, started in 2005, is built on the action research technique [12]. The model of MATRA REGIMA (the Dual Track Holistic Approach (DthA)) runs as a holistic system consisting of two process cycles: urban regeneration and community development. The outer circular development is based on the cycle of community development. The DthA model (Fig. 4) is designed by the stages of community development model that concerns planning, monitoring and learning for development [13] and a developmental cycle that provides social and economic changes at the neighborhood level [14].

DthA is figuring community development with the urban regeneration community, which can enable easier achievement of positive urban regeneration outcomes focusing on community values and benefits. By the time the urban regeneration practice of Ottoman Neighborhood is completed,

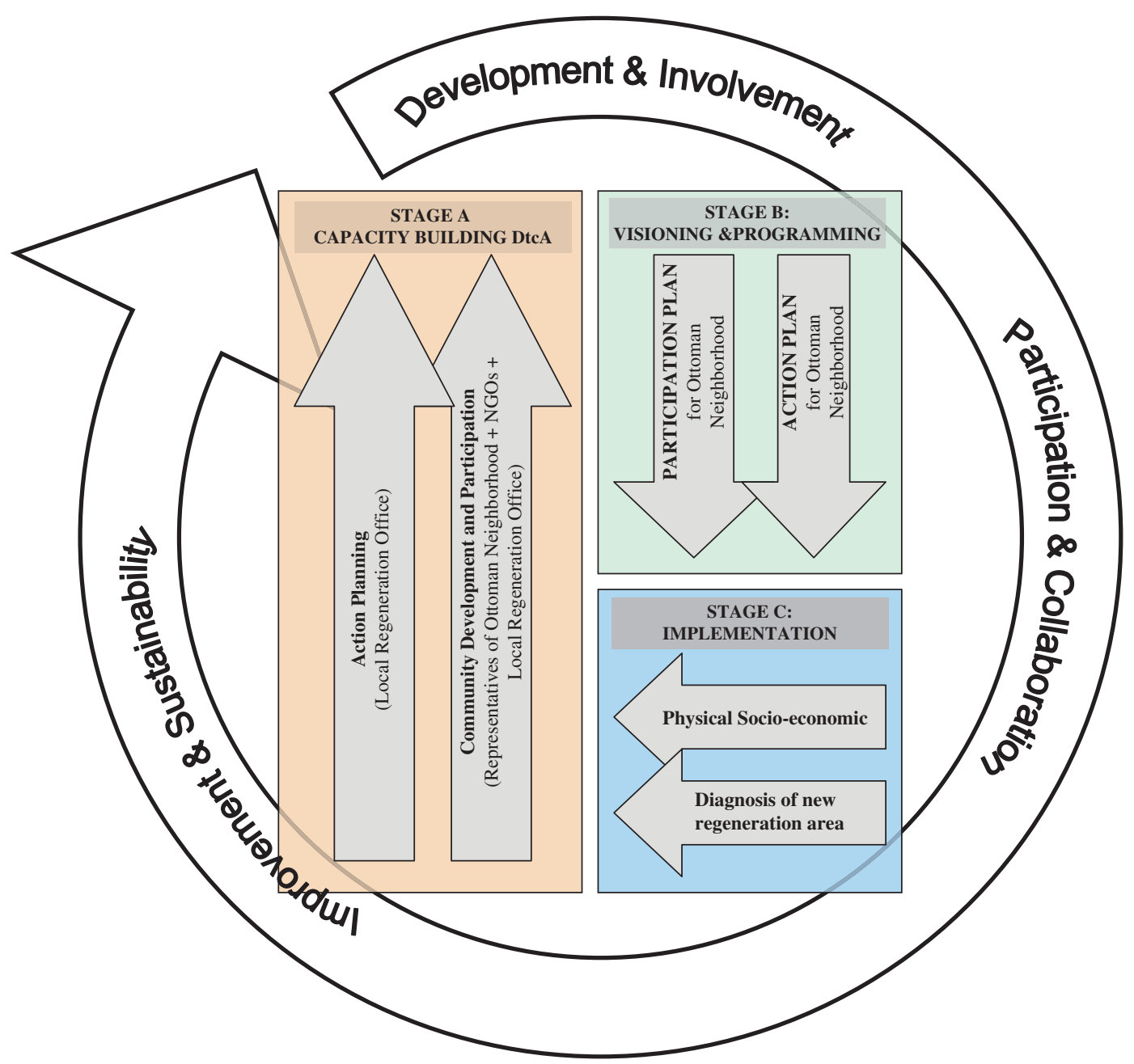

Figure 4: DthA of the Matra REGIMA Project. 
the local community with built capacity will convey its skills and knowledge to the community of another neighborhood under similar practice; thus, a new urban regeneration process will start in a new project area [15]. When the defined cycle is completed, urban regeneration and community development will also be fulfilled in the whole Culture Valley area.

Stages A, B, and C realize the urban regeneration process as the dual track cycle is carried out. The process describes a methodology for collaborative urban regeneration action based on an action research model as a cyclical process of visioning, planning, action, observation, and reflection [12]. Building from this model, a conceptual framework for capacity building articulates citizen, community group, and local government capacity building requirements to operate collaborative local action for a sustainable urban regeneration. As Chapman and Kirk [16] stress, community capacity should be planned and built within capacity building activities of urban regeneration programs. Such a capacity building will be a process affected by bottom-up local dynamics. Here, the community itself plays an important role in defining and prioritizing the common community needs. In the DthA model, the process deals with community development while building institutional capacity.

Mainly, there are three dual tracks in the DthA model, each belonging to a stage. The first dual track in Stage A is capacity building in the development and involvement phase. The second dual track in Stage B is visioning and programming in the participation and collaboration phases. Important outcomes of this stage are action plan and participation plan, which are developed due to capacities that have been developed. In the Ottoman neighborhood both plans were performed in this phase. In the third phase of Stage C, implementation is performed with the aim of improvement and sustainability. While the implementation of capacity building in the Ottoman neighborhood is being achieved, it will be started to develop for another neighborhood within the Zeytinburnu Culture Valley Project site. Thus, a new circular process for a new urban regeneration project area will be accomplished in the near future. Local municipality, community representatives, practitioners, university, and NGOs are involved in the DthA process. To achieve a successful planning and implementation experience, the Dual Track Capacity Approach (DtcA) in the first phase is the most important case for action planning and participatory planning.

\subsubsection{DtcA at the beginning of the regeneration process}

The Matra REGIMA Project provides opportunities for participants to develop skills and knowledge in communication and participation in relation to the urban built environment and to apply these skills in a group activity to prepare a strategy for urban regeneration in a pilot study. In this project, DtcA is developed, which allows local government to play a successful role in the urban regeneration process (Fig. 5). DtcA is reinforced by a concern to facilitate empowerment, to build knowledge and skills about both local government and neighborhood and to ensure flexibility in project design and feedback to communities. It also has the potential to impact on institutional capacity within areabased regeneration, structures and environments, and as such it aims to attract policy makers, practitioners, and communities with a genuine commitment to adapt the principles of local people's participation in the process of collaborative urban regeneration. The model is a logical framework of DtcA for enabling the urban regeneration, which assumes that capacity building for communities is as important as the institutional capacity building.

Using a DtcA model, the findings of the Matra REGIMA Project support existing evidence, which points to the importance of training on knowledge and skills during the regeneration process [16-18]. The training routes define the capacity building needs of the local municipality and the community of the pilot area. After each module, exercises for developing implementation skills take place with 


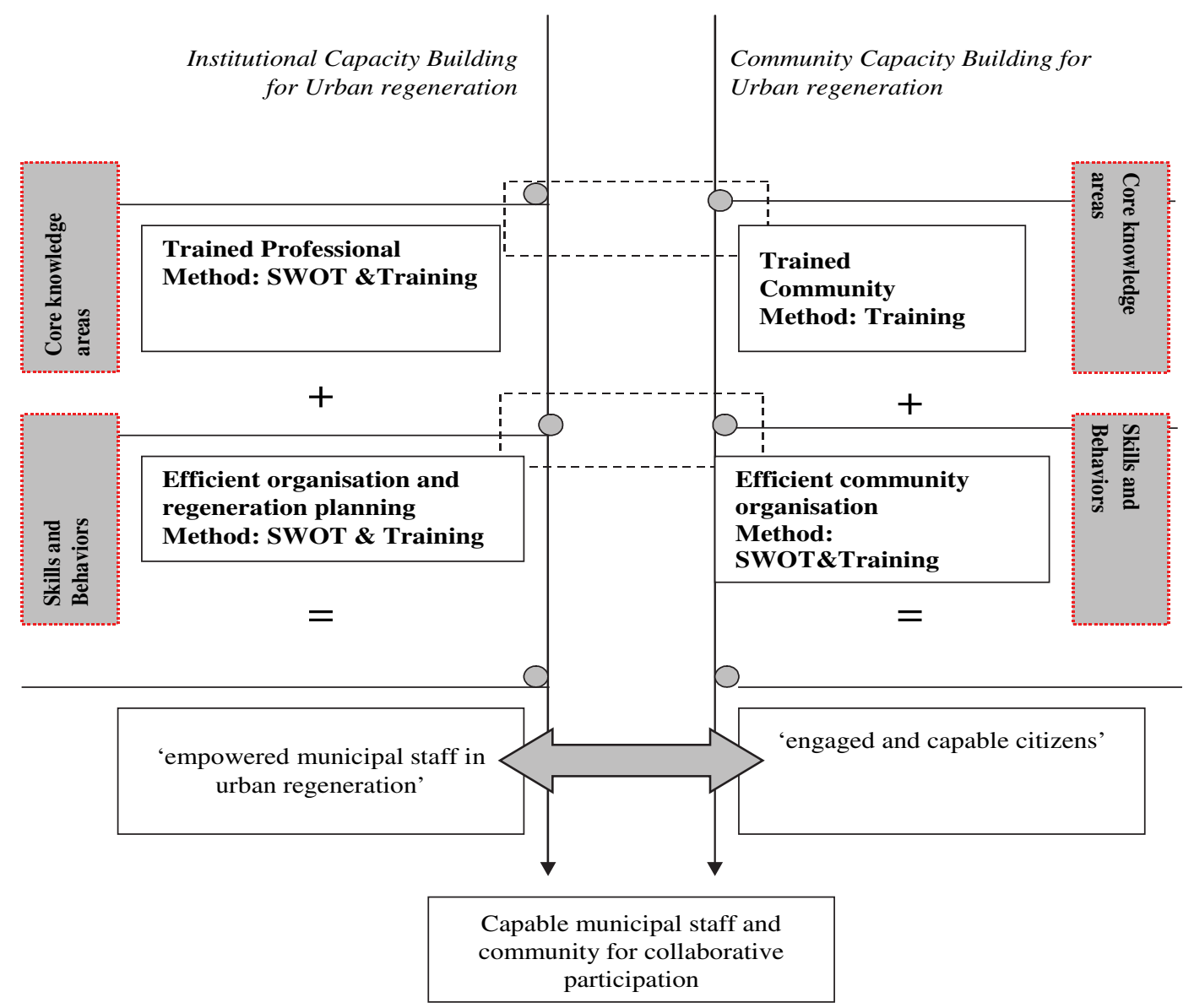

Figure 5: DtcA for sustainable participation in urban regeneration.

the participation of local municipality staff, NGOs, community representatives and the steering committee. Conducting these exercises and achieving solid practical outcomes require a pilot area that was determined as the Ottoman neighborhood within the Culture Valley Project.

\subsection{The Ottoman neighborhood as a Matra REGIMA pilot area}

The objectives of the Matra REGIMA project are to develop the capacity of the Zeytinburnu Municipality and local inhabitants for participation, strategic action planning and community development, and to provide applicability of these outcomes either in other urban regeneration projects in Zeytinburnu District or in other districts of Istanbul, as the need for sustainable urban approaches - especially participatory approaches - has risen, particularly in most of the districts after the 1999 Marmara earthquake. Following this earthquakes there is also an increasing demand for safer settlement areas and qualified building systems. In the process of adaptation to the EU, well-organized and highly standardized actors of the sector will also become the key instruments of urban development. 
The application method of the Matra REGIMA Project was set to meet the needs of Zeytinburnu Municipality and Istanbul in urban regeneration issues.

The Ottoman neighborhood is a residential area located between Merkezefendi Mosque and Yenikapi Mavlavi House within the Zeytinburnu Culture Valley Project site (Fig. 6). It is also integrated with the cultural axis combining the cultural focuses. The neighborhood hosts historic and cultural assets. Among the historic buildings, there are listed as well as unlisted ones. In Fig. 7, the buildings in blue circles represent listed historic buildings while the red circles show unlisted historic buildings. Merkezefendi Mosque and square, a historic hammam of Architect Sinan and the Mavlavi House from the Ottoman architecture are the most important assets of the area. Especially Mavlavi House and Merkezefendi Mosque are frequently visited by local inhabitants and foreigners. There are 19 parcels and 51 units. The number of storeys varies from one to three floors. An important aspect of the social structure is that the inhabitants of the Ottoman neighborhood hold 'local cultural knowledge' and that they have the willingness to realize revitalization of local economic structure and living together after regeneration.

\subsection{Milestones of the Matra REGIMA Project: theory into practice}

At the end of 1.5 years of the project duration, the expected outcomes of the Matra REGIMA Project are still being driven under DtcA. In Fig. 8, training modules of dual track capacity building are seen to be reflected in practicing process. Here it is shown that knowledge and skills components of the

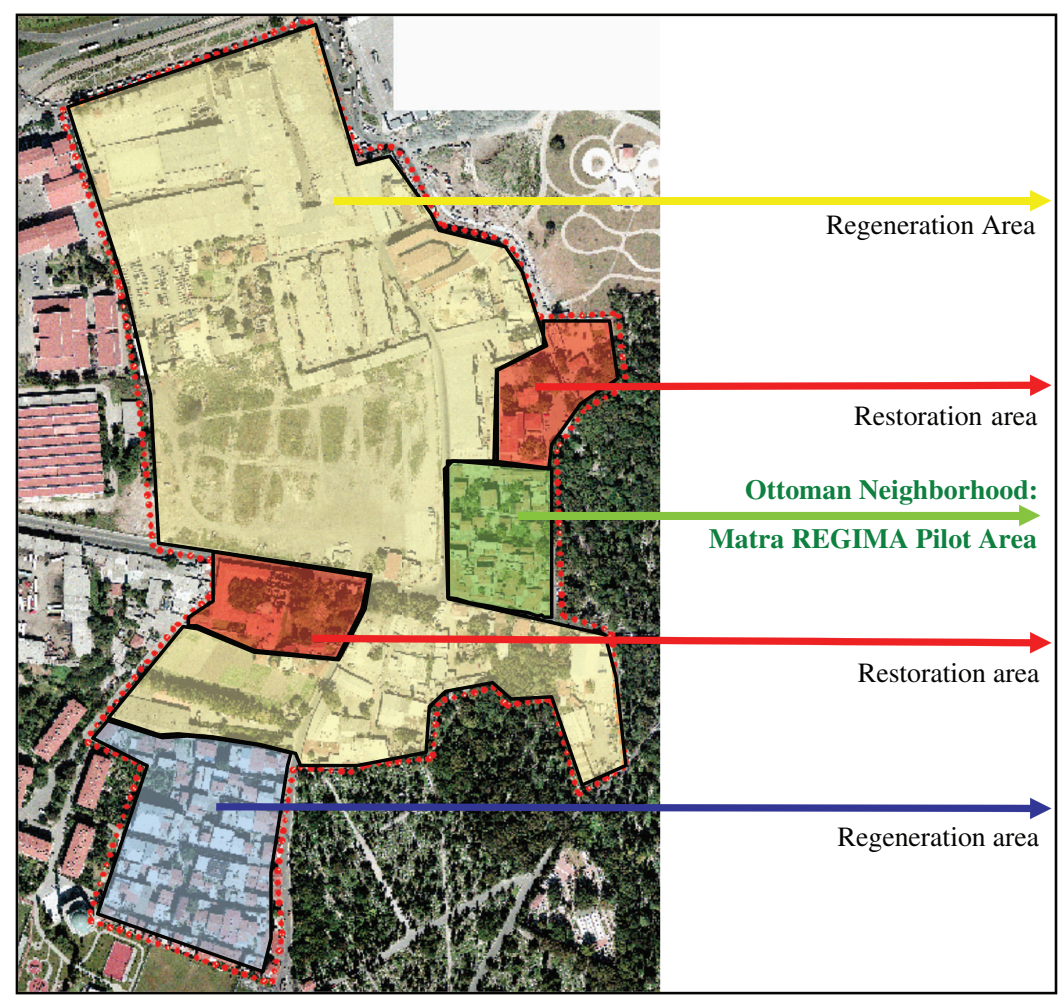

Figure 6: The Ottoman neighborhood in the Cultural Valley Project site. 


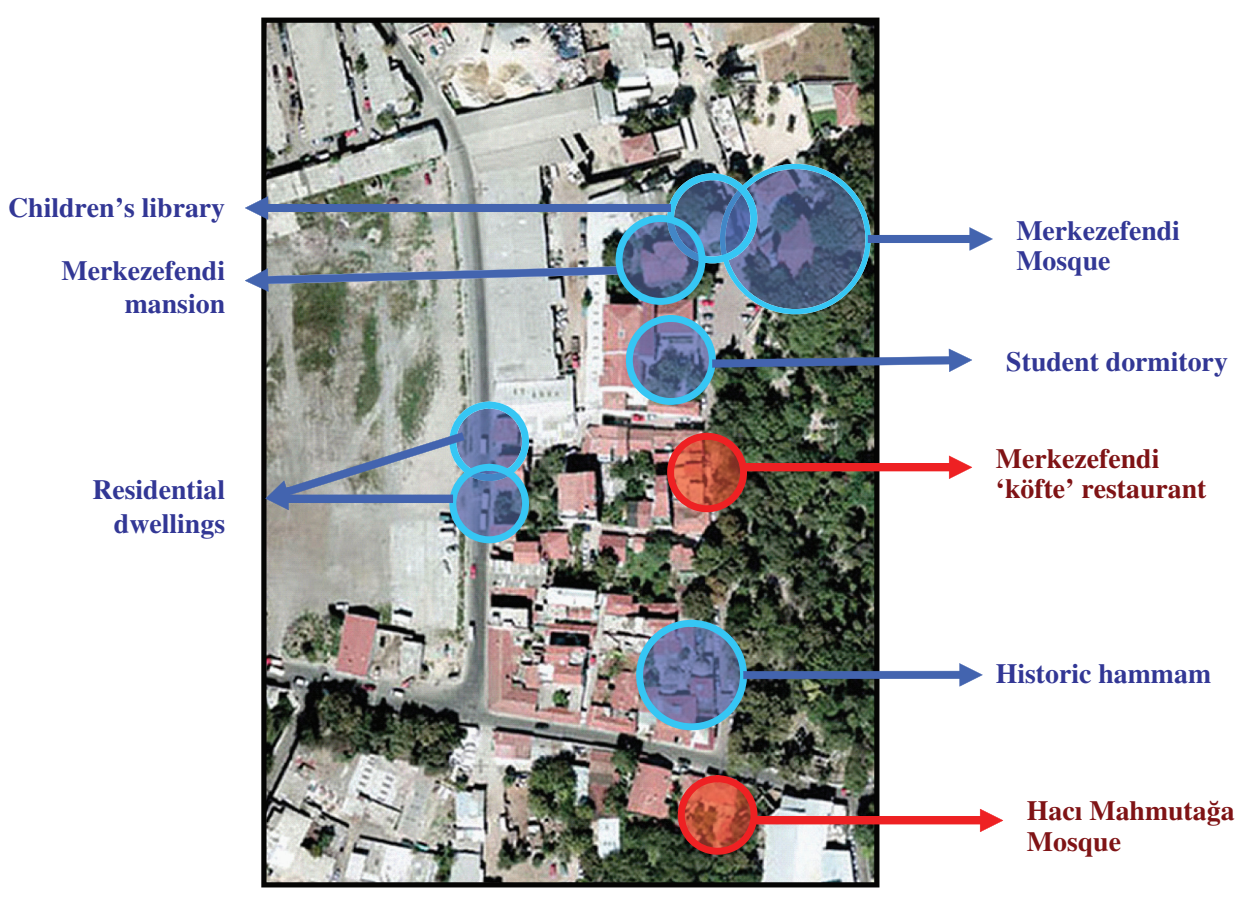

Figure 7: Historic assets of the Ottoman neighborhood.

strategic action planning track provide physical, legal, and financial milestones whereas the ones of the community development and participation track provide participation milestones. These milestones in time-bound relation can be shown in a timeline (Fig. 9). Each dot in Fig. 9 shows a milestone of the DtcA model representing a step of theory into practice process within 1.5 years of project duration. These milestones are categorized under three issues - legal, financial, and participation milestones - that reflect the capacity building program to actions. The planning process in which these milestones are integrated has followed several steps since January 2006. By June 2007 the implementation plan of the Ottoman neighborhood was approved by the National Board of Renewal. Inhabitants of the Ottoman neighborhood continue to collaborate with Zeytinburnu Municipality in order to realize the Ottoman neighborhood's vision with the slogan: 'Modern Ottoman neighborhood reflecting its history to future'. Thus, the Ottoman neighborhood case shows the training experience on capacity building for urban regeneration and community development in addition to the 'theory into practice' experience of local municipality as well as neighborhood inhabitants.

\section{CONCLUSION}

This study conveys the 'theory into practice' milestones of the Matra REGIMA Project in progress that was developed and conducted to support Zeytinburnu Municipality in sustainable urban regeneration practices. Milestones derived from the project highlight the roles of governance and capacity building in urban regeneration mentioned in the initial sections of this paper. By developing the necessary decision making and project management structures, Zeytinburnu Municipality has succeeded in including 'urban governance' and 'capacity building' in its strategic plan and 


\begin{tabular}{|c|c|c|c|}
\hline \multicolumn{4}{|c|}{$\begin{array}{l}\text { KICK OF STARTING FOR URBAN REGENERATION PROCESS: } \\
\text { CAPACITY BUILDING (Theory) and IMPLEMENTATION (Practice) }\end{array}$} \\
\hline $\begin{array}{c}\text { Local } \\
\text { Practitioners } \\
\text { NGOs, } \\
\text { inhabitants }\end{array}$ & & & $\begin{array}{c}\text { Local } \\
\text { Practitioners, } \\
\text { NGOs, } \\
\text { inhabitants }\end{array}$ \\
\hline \multicolumn{2}{|c|}{$\begin{array}{l}\text { STRATEGIC } \\
\text { ACTION PLANNING }\end{array}$} & \multicolumn{2}{|c|}{$\begin{array}{l}\text { COMMUNITY DEVELOPMENT \& } \\
\text { PARTICIPATION }\end{array}$} \\
\hline $\begin{array}{l}\text { Training Modules of } \\
\text { Capacity Building } \\
\text { Theory }\end{array}$ & $\begin{array}{l}\text { Milestones of the } \\
\text { builded Capacity } \\
\text { Into Practice }\end{array}$ & $\begin{array}{l}\text { Training Modules of } \\
\text { Capacity Building } \\
\text { Theory }\end{array}$ & $\begin{array}{l}\text { Milestones of the } \\
\text { builded Capacity } \\
\text { Into Practice }\end{array}$ \\
\hline $\begin{array}{l}\text { Theory } 1 \text {-Urban regeneration, } \\
\text { process, planning and } \\
\text { decision-making } \\
\text { Theory 2-Structure of project } \\
\text { organisation }\end{array}$ & $\begin{array}{l}\text { Practice1-Project } \\
\text { organisation of } \\
\text { Zeytinburnu Cultural } \\
\text { Valley Project } \\
\text { Practice 2-Establishing } \\
\text { of Steering Committe, } \\
\text { Agenda Group and } \\
\text { Zeytinburnu } \\
\text { Communication Unit } \\
\text { (ZCU) }\end{array}$ & $\begin{array}{l}\text { Theory 6- Public participation } \\
\text { \& Community Development }\end{array}$ & $\begin{array}{l}\text { Practice 6- } \\
\text { Communication \& } \\
\text { participation plan }\end{array}$ \\
\hline $\begin{array}{l}\text { Theory } 3 \text { - Strategic Action } \\
\text { planning: Determination of } \\
\text { strategic objectives on } \\
\text { communication \& participation }\end{array}$ & $\begin{array}{l}\text { Practice 3a-Strategic Plan } \\
\text { for Zeytinburnu Cultural } \\
\text { Valley } \\
\text { Practice 3b-Action Plan } \\
\text { for Merkez Efendi Pilot } \\
\text { Area }\end{array}$ & $\begin{array}{l}\text { Theory } 7 \text { - Operational } \\
\text { structure, business plan for } \\
\text { communication center }\end{array}$ & $\begin{array}{l}\text { Practice 7-Establishing } \\
\text { Communication Center }\end{array}$ \\
\hline Theory 4 - Financial Analysis & Practice 4-Financial Plan & $\begin{array}{l}\text { Theory } 8 \text { - Toolkits for } \\
\text { Operating Communication } \\
\text { Center }\end{array}$ & $\begin{array}{l}\text { Practice 8-Operating } \\
\text { Neighborhood } \\
\text { Communication Center }\end{array}$ \\
\hline Theory 5 - Legal Knowledge & $\begin{array}{l}\text { Practice 5-Legal } \\
\text { Strategic Plan }\end{array}$ & $\begin{array}{l}\text { Theory 9-Toolkits for Public } \\
\text { Participation }\end{array}$ & $\begin{array}{l}\text { Practice 9-Facilitating } 3 \\
\text { Public events }\end{array}$ \\
\hline
\end{tabular}

Figure 8: Framework and training modules of DtcA.

implementing these with the support of the Matra REGIMA Project. The achievements of local municipality and inhabitants are stated below:

- increased number of community-based opportunities;

- enhanced ability of members to share their ideas and actions for change;

- increased capability in setting and achieving goals;

- enhanced respect for limited resources;

- achieved confidence of its inhabitants due to urban regeneration implementation efforts before the expected earthquake. 


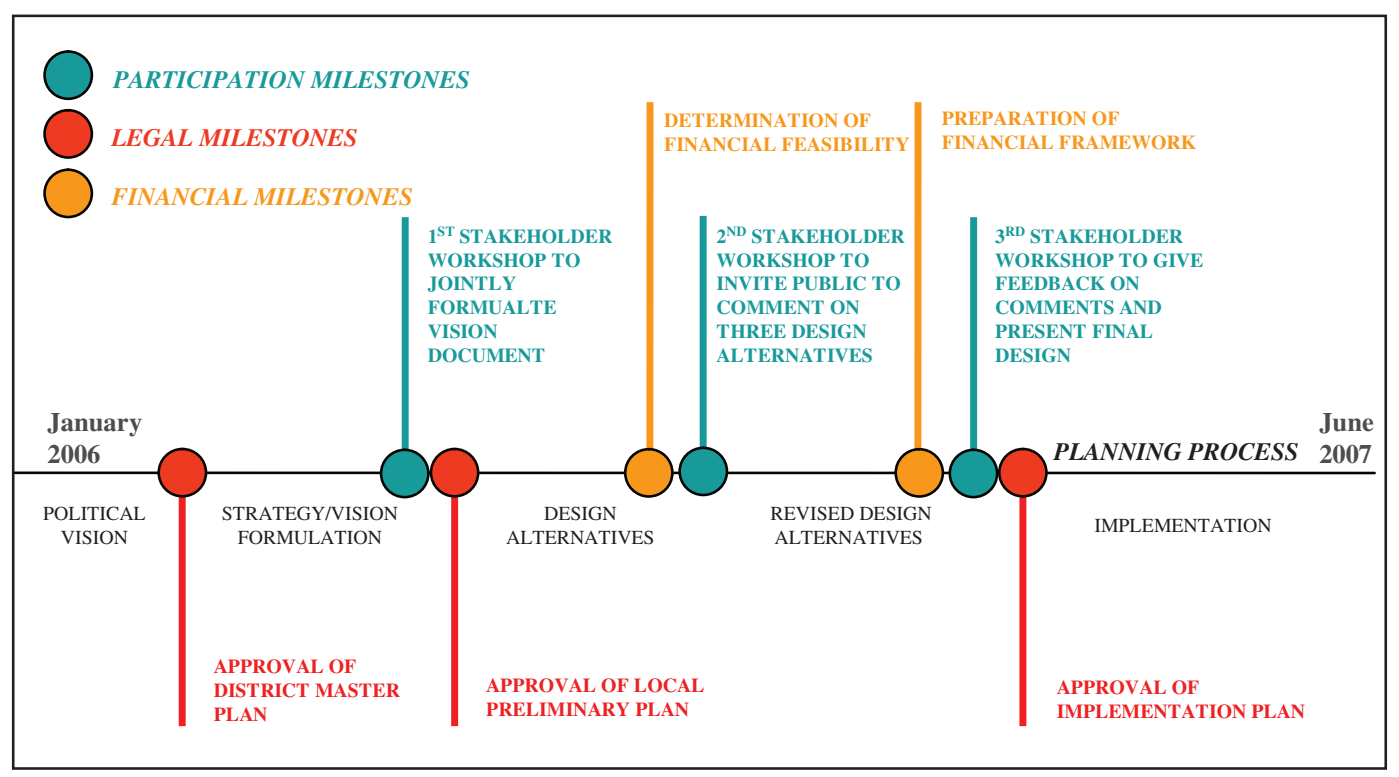

Figure 9: Timeline for the Ottoman neighborhood regarding planning, legal, financial and participation processes.

Despite all difficulties, the Matra REGIMA Project has made a significant contribution in regeneration initiatives in the Ottoman neighborhood. In particular, DthA produced a range of flexible and coherent responses in relation to esteem-building, community development and new modes of learning and training. The project was also significant in that it aimed to break down the traditional barriers and institutionalized formats that discouraged wider-scale participation in training programs. On strategically looking towards urban regeneration, the outcomes of the Matra REGIMA Project give the clue that a well-established organization as well as a skilled municipality team and community can be handled together within a process. The project's outcomes reveal the importance of shared and enriched local knowledge to establish intellectual capital; the priority of extending stakeholder involvement and linkages between networks to provide social capital; and the absence of trust between community, local government and NGOs to strengthen politic capital. With the support of the Matra Project, Zeytinburnu Municipality serves as a successful case for 'urban governance', which has accelerated in the 2000s in Turkey through the 'coalition' of academicians, NGOs, community representatives and inhabitants.

\section{REFERENCES}

[1] Lang, T., Insights in the British Debate about Urban Decline and Urban Regeneration, Working paper, http://www.irs-net.de, 2005.

[2] Roberts, P., The evolution, definition, and purpose of urban regeneration. Urban Regeneration: A Handbook, eds P. Roberts \& H. Skyes, London, 2000.

[3] Carter, A., Strategy and partnership in urban regeneration. Urban Regeneration: A Handbook, eds P. Roberts, \& H. Skyes, London, 2000.

[4] Elander, I., Partnership and urban governance. International Social Science Journal, 172, pp. 191-204, 2002. 
[5] UNCHS (United Nations Centre for Human Settlements) Habitat Agenda and Istanbul Declaration, Second United Nations Conference on Human Settlements, Istanbul, United Nations Department of Public Information, 1996.

[6] UNCED, Agenda 21, United Nations, New York, 1992.

[7] Khakee, A., Assessing institutional capital building in a Local Agenda 21 process in Goteborg. Planning Theory \& Practice, 3(1), pp. 53-68, 2002.

[8] Healey, P., Collaborative Planning: Shaping Places in Fragmented Societies, Macmillan: London, 1997.

[9] Ozcevik, O., Turk, S., Beygo, C. \& Akcakaya, I., Sustainable Urban Regeneration in the Republic of Turkey (Matra REGIMA), Netherlands Ministry of Foreign Affairs, PRC Divisie Bouwcentrum BV, Project Report, 2007.

[10] Sener, S., Ozcevik, O., Altun, C., Sener, E. \& Akcakaya, I., Post Disaster Temporary Shelter Settlement Pattern and Unit Development Project for Istanbul, The Metropolitan Municipality of Istanbul and Istanbul Technical University, Urban and Environmental Planning Research Center, Project Report, 2003.

[11] Matra Social Transformation Program, http://www.minbuza.nl.

[12] Zuber-Skerrit, O., New Directions in Action Research. The Falmer Press: London, 1991.

[13] Barr, A. \& Hashagen, S., ABCD Handbook - A Framework for Evaluating Community Development, Glasgow, Scottish Community Development Centre, 2000.

[14] Banks, S. \& Shenton, F., Regenerating neighbourhoods: a critical look at the role of community capacity building. Local Economy, 16(4), pp. 286-298, 2001.

[15] Beygo, C., Ozcevik, O., Turk, S.S., Akcakaya, I., Sen, K. \& Damen, T., Milestones of Zeytinburnu Municipality through sustainable urban regeneration: from vision to action. 42nd ISoCaRP Congress, Yildiz Technical University: Istanbul, 2006.

[16] Chapman, M. \& Kirk, K., Lessons for Community Capacity Building: A Summary of Research Evidence, A Research Review to Scottish Homes, Scottish Homes: Edinburgh, 2001.

[17] Mayo, M., Learning for active-citizenship: training for and learning from participation in area regeneration. Studies in the Education of Adults, 32(1), pp. 22-35, 2000.

[18] O'Malley, L., Working in partnership for regeneration - the effect of organisational norms on community groups. Environment and Planning A, 36(5), pp. 841-857, 2004. 